\title{
Dosage schedule for intravenous aminophylline in apnoea of prematurity, based on pharmacokinetic studies
}

\author{
ROSAMOND A. K. JONES AND EIVOR BAILLIE \\ Hammersmith Hospital, London
}

SUMMARY 15 preterm infants were treated for recurrent apnoea with theophylline. 5 were given oral choline theophyllinate, but this was erratically absorbed. 14 were given IV aminophylline on 23 occasions. Apparent volume of distribution of theophylline in 12 infants was $0 \cdot 71 \pm 0 \cdot 181 / \mathrm{kg}$ $($ mean $\pm \mathrm{SD})$. Plasma clearance rate measured in 11 infants at steady state was $18 \cdot 6 \pm 4 \cdot 8 \mathrm{ml} / \mathrm{kg}$ per hour. Calculations show that a loading dose of $6.2 \mathrm{mg} / \mathrm{kg}$ aminophylline intravenously and maintenance of $4.4 \mathrm{mg} / \mathrm{kg}$ per day would produce serum levels of between 6 and $12 \mathrm{mg} / 1 \mathrm{in}$ all but one of the infants studied, with no infant having toxic levels.

Recurrent apnoea is a common complication of prematurity, carrying a high morbidity and mortality. Kuzemko and Paala (1973) first showed that rectal aminophylline reduced apnoeic attacks, and Shannon et al. (1975) subsequently showed that oral theophylline was also effective. The therapeutic range in newborn babies is probably lower than in children and adults, as shown by the clinical effect (Shannon et al., 1975) and the reduced protein binding (Aranda et al., 1976). Published dosage schedules are scanty. Aranda et al. (1976) studied pharmacokinetics of IV aminophylline in 6 newborn infants given a single dose, and from their calculations of volumie distribution and clearance they recommended a loading dose of $6.9 \mathrm{mg} / \mathrm{kg}$ aminophylline and maintenance of $4 \cdot 1 \mathrm{mg} / \mathrm{kg}$ per day (equivalent to 5.5 and $3.3 \mathrm{mg}$ respectively of pure theophylline). Shannon et al. (1975) suggested oral theophylline dosage of $2 \cdot 5 \mathrm{mg} / \mathrm{kg}$ 6-hourly based on a single blood level on the 2 nd day of treatment in 17 infants. The absence of a loading dose in this regimen means delay in reaching therapeutic levels. Moreover, the high daily dose may lead to accumulation if continued for several days. Giacoia et al. (1976) using oral slow-release theophylline(Slophylline) $2 \mathrm{mg} / \mathrm{kg}$.6hourly found toxic levels after 3 to 4 days' treatment in 6 of 8 infants. Rectal suppositories may be traumatic to insert and it is difficult to adjust the dose accurately.

Department of Paediatrics and Neonatal Medicine, Hammersmith Hospital, London

ROSAMOND A. K. JONES, paediatric registrar

EIVOR BAILLIE, research technician
This study aimed to look at pharmacokinetics of aminophylline over a complete course of treatment, in order to suggest a safe maximum dose avoiding toxic levels.

\section{Patients and methods}

Fifteen preterm infants with recurrent apnoea entered the study. Treatment was started if an infant had 2 apnoeic attacks within 6 hours or 3 within 24 hours, defined as apnoea of more than 20 seconds with associated bradycardia or cyanosis. All infants had a full infection screen including lumbar puncture and chest $x$-ray, and were excluded if a cause for apnoea was found apart from prematurity. Gestations ranged from 25 to 31 weeks (mean $28 \cdot 1$ ) and birthweights from 700 to $1400 \mathrm{~g}$ (mean 1125), all infants being of appropriate weights for gestation.

Oral treatment was with choline theophyllinate given via a gastric tube. IV treatment was with aminophylline (theophylline ethylene diamine) using a loading dose given over 20 minutes and maintenance given as a continuous infusion via a peripheral vein.

Levels were measured on $25 \mu \mathrm{l}$ serum, using high pressure liquid chromatography (McKenzie et al., 1978). Samples were taken 2 hours after an oral dose or one hour after the IV loading dose and every 12 to 24 hours during maintenance treatment, aiming to keep serum levels between 6 and $12 \mathrm{mg} / \mathrm{l}$.

Analysis of data. Pharmacokinetic parameters were only calculated for IV treatment. The dose of 
aminophylline was taken to be equivalent to $80 \%$ pure theophylline and a single compartment model was assumed (Loughnan et al., 1976). The following formulae were used.: Volume distribution $=\frac{\text { loading dose } \mathrm{mg} / \mathrm{kg}}{\text { one hour level } \mathrm{mg} / \mathrm{l}}$
$1 / \mathrm{kg}$

maintenance dose $\mathrm{mg} / \mathrm{kg}$

Clearance $\mathrm{ml} / \mathrm{kg}=\frac{\text { per hour } \times 10^{3}}{\text { steady state level } \mathrm{mg} / 1}$ per hour

In children given IV aminophylline, Loughnan et al. (1976) showed that a single one-hour level gave comparable results for volume distribution to 6 repeated levels within the hour, thus avoiding the need for frequent samples. Clearance was calculated when blood levels had remained steady for a minimum of 2.4 hours. Four infants had 3 or more levels measured after stopping treatment and half-life was estimated by linear regression analysis using a computer.

\section{Results}

Oral treatment. Three infants were treated initially with choline theophyllinate. Doses and blood levels are shown in Table 1 . The first infant was given a standard dose of $2.5 \mathrm{mg} / \mathrm{kg}$ 6-hourly, but after 3 doses serum levels were still subtherapeutic
Table 1 Serum theophylline levels after oral choline theophyllinate

\begin{tabular}{lccl}
\hline Infant & Dose $(\mathrm{mg} / \mathrm{kg})$ & Dose interval & $\begin{array}{l}\text { Serum level 2 } \\
\text { hours after each } \\
\text { dose }(\mathrm{mg} / \mathrm{l})\end{array}$ \\
\hline 1 & 2.5 & 8-hourly $\times 3$ & $4,2,2$ \\
2 & 7.7 & 12-hourly $\times 2$ & 2,1 \\
3 & 10.9 & Single dose & 1 \\
\hline
\end{tabular}

and severe apnoea necessitated ventilation. The next 2 infants were given higher loading doses of $7 \cdot 7$ and $10.9 \mathrm{mg} / \mathrm{kg}$ respectively, but one infant developed bile-stained vomiting and in both absorption was inadequate. Apnoea persisted and both infants were changed to IV aminophylline which was used in all subsequent cases.

Two further infants who were treated with IV aminophylline with good effect were later changed to maintenance with oral choline theophyllinate $(1.5 \mathrm{mg} / \mathrm{kg}$ 6-hourly). Both maintained adequate serum levels but one developed vomiting and diarrhoea and returned to IV treatment.

Intravenous amninophylline. Fourteen infants were given 23 courses of treatment. The results of all pharmacokinetic estimates are shown in Table 2. The initial loading dose ranged from $5 \cdot 1-7 \cdot 8 \mathrm{mg} / \mathrm{kg}$, and one-hour serum levels in 12 infants were between 7 and $10 \mathrm{mg} / \mathrm{l}$ in 11 infants, and only $4 \mathrm{mg} / \mathrm{l}$ in the 12 th.

Table 2 Pharmacokinetic parameters in 14 infants given IV aminophylline

\begin{tabular}{|c|c|c|c|c|c|c|c|}
\hline \multirow[t]{2}{*}{ Case } & \multirow{2}{*}{$\begin{array}{l}\text { Gestation at } \\
\text { birth (weeks, } \\
\text { days) }\end{array}$} & \multicolumn{2}{|c|}{ Volume distribution } & \multicolumn{2}{|l|}{ Clearance } & \multicolumn{2}{|l|}{ Half life } \\
\hline & & $(l / k g)$ & Age (days) & (ml/kg per hour) & Age (days) & (Hours) & Age (days) \\
\hline 1 & 28,0 & 0.71 & 4 & $24 \cdot 2$ & $4-6$ & - & 一 \\
\hline 2 & 27,0 & 0.50 & 4 & $19 \cdot 0$ & 4-7 & - & 一 \\
\hline 3 & 26,0 & 0.63 & 4 & - & - & - & 一 \\
\hline 4 & 25,1 & $\begin{array}{l}0.65 \\
0.82\end{array}$ & $\begin{array}{r}3 \\
30\end{array}$ & $20 \cdot 4$ & $4-10$ & - & - \\
\hline 5 & 29,0 & 0.65 & 30 & $17 \cdot 2$ & $31-32$ & - & - \\
\hline 6 & 27,0 & $\begin{array}{l}0.77 \\
0.52\end{array}$ & $\begin{array}{r}0 \\
15\end{array}$ & $13 \cdot 7$ & $0-2$ & - & - \\
\hline 7 & 28,3 & 0.78 & 9 & - & - & $\begin{array}{l}34 \cdot 8 \\
28 \cdot 6\end{array}$ & $\begin{array}{l}10-11 \\
16-18\end{array}$ \\
\hline 8 & 27,1 & $\begin{array}{l}0.62 \\
0.42\end{array}$ & $\begin{array}{l}19 \\
29\end{array}$ & $\begin{array}{l}13 \cdot 3 \\
17 \cdot 7\end{array}$ & $\begin{array}{l}20-21 \\
29-32\end{array}$ & $\overline{45} \cdot 1$ & $\overline{32}-34$ \\
\hline 9 & 28,0 & 0.68 & 36 & $27 \cdot 9$ & $37-39$ & - & - \\
\hline 10 & 29,3 & 0.68 & 10 & - & - & 一 & - \\
\hline $11 \mathrm{~T}_{\mathrm{w}}$ & 29,0 & 0.60 & 7 & $17 \cdot 6$ & $12-17$ & - & $\overline{14}$ \\
\hline $12 \int^{1}$ & 29,0 & $1 \cdot 22$ & 10 & $\begin{array}{l}21 \cdot 8 \\
15 \cdot 8\end{array}$ & $\begin{array}{l}10-13 \\
18-21\end{array}$ & $28 \cdot 2$ & $14-15$ \\
\hline 13 & 30,0 & - & - & $12 \cdot 3$ & $18-20$ & $\overline{1}$ & $\overline{10}$ \\
\hline 14 & 27,2 & $\begin{array}{l}0.098^{*} \\
0.47\end{array}$ & $\begin{array}{l}10 \\
19\end{array}$ & $\overline{17} \cdot 0$ & $\overline{25} \cdot 28$ & $27 \cdot 0$ & $10-13$ \\
\hline $\begin{array}{l}\text { Mean } \\
\text { SD } \\
\text { Range } \\
\text { No. of }\end{array}$ & $\begin{array}{l}27,9 \\
\pm 1 \cdot 4 \\
25 \cdot 1-30 \cdot 0\end{array}$ & $\begin{array}{l}0.70 \dagger \\
\pm 0.18 \\
0.42-1 \cdot 22\end{array}$ & & $\begin{array}{l}18 \cdot 6 \dagger \\
\pm \quad 4 \cdot 8 \\
12 \cdot 3-27 \cdot 9\end{array}$ & & $\begin{array}{l}33 \cdot 8 t \\
+\quad 8 \cdot 3 \\
27 \cdot 045 \cdot 1\end{array}$ & \\
\hline infants & 14 & 12 & & 11 & & 4 & \\
\hline
\end{tabular}

† Means use results of first measurements only in infants who were remeasured.

* Omitted from calculation of mean, see text. 
Volume distribution calculated for these 12 infants was $0.71 \pm 0.18 \mathrm{l} / \mathrm{kg}$ (mean $\pm \mathrm{SD}$ ). In one infant the one-hour blood sample was missed and the 14th infant was omitted from the calculation of mean volume distribution. This infant, given $6.6 \mathrm{mg} / \mathrm{kg}$, had a one-hour serum level of $54 \mathrm{mg} / \mathrm{l}$, giving a volume distribution of $0.098 \mathrm{l} / \mathrm{kg}$, far lower than any other infant studied. It seems likely that there was an error in the dose given, particularly as the drug was eliminated normally and, moreover, when given a further course of treatment 9 days later he showed a volume distribution of $0.47 \mathrm{l} / \mathrm{kg}$.

Volume distribution was calculated in 3 infants during a 2 nd course of treatment. In 2 the value was higher and in one it was lower. Volume distribution was unrelated to gestational or postnatal age. Taking all measurements of volume distribution there was a 3 -fold variation from 0.42 to $1 \cdot 221 / \mathrm{kg}$.

Maintenance infusions were adjusted by twice daily levels to keep within the therapeutic range. Clearance was calculated in 11 infants while on a constant infusion rate over a mean of 67 hours and was $18.6 \pm 4.8 \mathrm{ml} / \mathrm{kg}$ per hour (mean $\pm \mathrm{SD}$, range 12.3 to $27.9 \mathrm{ml} / \mathrm{kg}$ per hour). Again this was unrelated to gestational or postnatal age. Half life measured in 4 infants was $33 \cdot 8 \pm 8 \cdot 3$ hours.

Effect of treatment. During 23 courses of IV aminophylline, apnoea was completely abolished in 11, reduced in 5 , and unaltered in 7 . However, no control group was used. Levels falling below $5 \mathrm{mg} / 1$ were associated with recurrence of apnoea. Of 3 infants reaching levels above $20 \mathrm{mg} / \mathrm{l}$, one had a sinus tachycardia of $240 /$ minute and was irritable, the other 2 remaining symptom-free. Three infants developed cardiac failure with a patent ductus arteriosus, one responding to digitalisation and 2 to indomethacin. All 3 had required ventilation before treatment with aminophylline, but animal in vitro work suggests that theophylline delays duct closure (Kreil et al., 1973). Two of these infants developed hyponatraemia (serum sodium 122 and $108 \mathrm{mmol} / \mathrm{l}$ ) after a dose of frusemide, and the diuretic effect of theophylline may have contributed.

Recommended dose of IV aminophylline. Using the formulae described in Methods, it was calculated that a loading dose of $6 \cdot 2 \mathrm{mg} / \mathrm{kg}$ would give a onehour level of $12 \mathrm{mg} / \mathrm{l}$ in the infant with the lowest volume distribution. Thus, this dose would be safe for all the infants studied with none reaching toxic levels and only one infant having subtherapeutic levels. Similarly using clearance estimations, a maintenance dose of $4.4 \mathrm{mg} / \mathrm{kg}$ per day would be a safe maximum, again with no infant reaching levels above $12 \mathrm{mg} / \mathrm{l}$ but one remaining subtherapeutic.

\section{Discussion}

Although the therapeutic range of theophylline in preterm newborns is not clearly defined, we found the range of 5 to $12 \mathrm{mg} / \mathrm{l}$ to be effective. Shannon et al. (1975) found tachycardia above 180 /minute in all infants with levels of $13 \mathrm{mg} / 1$ or over but in no infant with a level of $11 \mathrm{mg} / \mathrm{l}$ or less. Levels above $12 \mathrm{mg} / \mathrm{l}$ are unnecessary and must be presumed to increase the risk of unwanted effects.

We found oral choline theophyllinate to be inadequately absorbed in these small sick infants. It may cause vomiting, particularly hazardous in an infant with recurrent apnoea, and there may be considerable delay before therapeutic levels are reached. We therefore feel it is not suitable for emergency use but could be used as maintenance treatment in infants free from severe apnoea who are absorbing feeds. Rectal aminophylline solution has been shown in adults to give a similar blood level to that by the intravenous route (Truitt et al., 1950) and though we have not used it, it would seem a reasonable alternative for maintenance if drips fail and oral absorption is poor.

We found IV aminophylline to be immediately effective, but we would stress that great care is needed to calculate and dilute the tiny doses. Our estimates of volume distribution are similar to those of Aranda et al. (1976) but our recommended loading dose is lower than theirs as we have calculated a safe maximum dose for all infants studied rather than using mean results. Our recommended maintenance dose is higher than theirs, yet remains safe for their infants too. A recent abstract of work by Assael et al. (1977) studying 7 infants, reports a volume distribution as low as $0.19 \mathrm{l} / \mathrm{kg}$. If one were to use a dose low enough to be safe for such an infant, then none of the infants studied by ourselves or by Aranda et al. (1976) would even reach the therapeutic range. Unfortunately there is such variability and unpredictability in distribution and clearance of this potent drug that we would only recommend its use if it is possible to measure serum levels regularly. Furthermore, very little is known about the effect of theophylline on the developing brain, and we believe it should be reserved for use in infants in whom repeated stimulation has failed. Long-term follow-up studies will be needed to compare those survivors of severe recurrent apnoea treated with theophylline with those treated with some form of respiratory support, before its final place can be judged.

We thank Dr Pamela Davies for encouragement, Mr John Meek for help with the assays, and Dr D. S. Davies for advice with the pharmacokinetics. 


\section{References}

Aranda, J. V., Sitar, D. S., Parsons, W. D., Loughnan, P. M., and Neims, A. H. (1976). Pharmacokinetic aspects of theophylline in premature newborns. New England Journal of Medicine, 295, 413-416.

Assael, B. M., Caccamo, M. L., Gerna, M., Latini, R., Mandelli, M., Marini, A., Sereni, F., and Tognoni, G. (1977). Theophylline pharmacokinetics in the premature neonate (abstract). Pediatric Research, 11, 1013.

Giacoia, G., Juskc, W. J., Menke, J., and Koup, J. R. (1976). Theophylline pharmacokinetics in premature infants with apnea. Journal of Pediatrics, 89, 829-832.

Kreil, E., Zapol, W., Sharp, G., Ayromlooi, J., Abrahams, S., and Kitz, R. (1973). Effects of cyclic AMP on isolated ductus arteriosus (abstract). Pediatric Research, 7, 300.

Kuzemko, J. A., and Paala, J. (1973). Apnoeic attacks in the newborn treated with aminophylline. Archives of Disease in Childhood, 48, 404-406.

Loughnan, P. M., Sitar, D. S., Ogilvie, R. I., Eisen, A., Fox, Z., and Neims, A. H. (1976). Pharmacokinetic analysis of the disposition of intravenous theophylline in young children. Journal of Pediatrics, 88, 874-879.
McKenzie, S. A., Edmunds, A. T., Baillie, E., and Meek, J. H. (1978). Clinical applications of serum theophylline measurement by high pressure liquid chromatography. Archives of Disease in Childhood, 53, 322-325.

Shannon, D. C., Gotay, F., Stein, I. M., Rogers, M. C., Todres, I. D., and Moylan, F. M. B. (1975). Prevention of apnea and bradycardia in low-birthweight infants. Pediatrics, 55, 589-594.

Truitt, E. B., Jr, McKusick, V. A., and Krantz, J. C., Jr (1950). Theophylline blood levels after oral, rectal, and intravenous administration, and correlation with diuretic action. Journal of Pharmacology and Experimental Therapeutics, 100, 309-315.

Correspondence to Dr R. A. K. Jones, Hammersmith Hospital, Department of Paediatrics and Neonatal Medicine, Du Cane Road, London W12 OHS.

Received 11 July 1978 